\title{
Transition in-and-out of exporting and its impact on employment growth
}

\author{
Esteban Lafuente ${ }^{1}$ \\ Department of Management, Universitat Politècnica de Catalunya (UPC Barcelona Tech) \\ EPSEB, Av. Gregorio Marañón, 44-50, 2da planta. 08028. Barcelona. Spain \\ Tel. +34 93405 4476, Fax: + 34933348960 \\ Email: esteban.lafuente@upc.edu
}

\section{Yancy Vaillant}

Department of Strategy and Entrepreneurship. Toulouse Business School (TBS)

1 Place Alphonse Jourdain, 31068 TOULOUSE Cedex 7, France

Email: y.vaillant@tbs-education.org

and

Departamento de Gestión Organizacional, Universidad de la Costa

Calle No 58, 55-66. Barranquilla, Colombia

\section{Jorge Moreno-Gómez}

Departamento de Gestión Organizacional, Universidad de la Costa

Calle No 58, 55-66. Barranquilla, Colombia

Email: jmoreno@cuc.edu.co

\section{PLEASE CITE AS:}

Lafuente, E., Vaillant, Y, Moreno-Gómez, J. (2018). Transition in-and-out of exporting and its impact on employment growth. International Journal of Emerging Markets, 13(6), 1907-1927. doi: 10.1108/IJoEM-08-2017-0306

\footnotetext{
${ }^{1}$ Corresponding author
} 


\title{
Transition in-and-out of exporting and its impact on employment growth
}

\begin{abstract}
:
Purpose: This study evaluates how different strategic choices related to the transitions in-andout of exporting (export entry, export persistence, export exit) impact employment growth in Romanian small and medium-sized businesses.

Design/methodology/approach: Using linear regression models on a sample of 566 Romanian SMEs, we model employment growth as a function of three different dimensions of foreign market participation: export entry, persistence, and exit.

Findings: Results indicate that exporting is positively associated with employment growth. The findings reveal that the different strategic choices linked to exporting have a differentiating impact on employment growth: while employment growth is more pronounced among new exporters which points to the presence of an impulse effect of exporting, businesses that interrupt their exporting activities report employment losses.

Research limitations/implications: This study underlines the relevance of distinguishing the specific impact of the different export behaviours related to the transitions in-and-out of exporting.

Practical implications: The results of the study fuel the debate on the relevance of promoting policies that encourage exporting among small businesses operating in emerging economies.

Originality/value: This study presents an original analysis of the distinctive effect that different forms of export behaviour related to the transitions in-and-out of exporting have on employment growth. The relevance of this study not only flows from the particular empirical design that simultaneously evaluates different export choices and their specific impact on employment growth.
\end{abstract}

Keywords: Internationalisation, export behaviour, export choices, export propensity, export entry, export persistence, export exit, employment growth, SMEs, Romania.

Article classification: Research paper 


\section{Transition in-and-out of exporting and its impact on employment growth}

\section{Introduction}

Internationalisation of sales, more concretely exporting, has been invoked as a relevant strategy that helps small and medium-sized enterprises (SMEs) to achieve their growth potential (Manolova et al., 2010; Ngo et al., 2016). Exporting SMEs in the European Union (EU) show higher average returns and employment growth levels, as well as greater innovation rates than their non-internationalised counterparts (European Commission, 2010; Lamb et al., 2011). It is thus fundamental for Europe to increase the capacity and effective export-based internationalisation of SMEs (European Commission, 2016). Additionally, exporting is a vital component for the sustained growth and development of SMEs in transition economies such as the Central and Eastern European countries, which are progressively exploring opportunities in overseas markets as a result of the access to European markets (European Commission, 2016).

Although SMEs increasingly engage in higher-commitment entry modes (Dimitratos et al., 2010), exports remain the most common mechanism chosen by SMEs to go into overseas markets (Morgan et al., 2012). Exporting is especially appealing to SMEs as it represents a lowcommitment entry mode and, therefore, the economic cost and risk borne by the entrepreneur are lower compared to alternative foreign entry modes (Manolova et al., 2010).

Nevertheless, SMEs realise at different intensities the generally positive effects of export activities (Crick, 2003), and the question of whether exporting is truly a sustainable strategy for SMEs can therefore be asked. Are the benefits of the export decision—in terms of employment growth—for first-time exporters comparable to those reported by businesses with more experience in international markets? Or to the contrary, and as suggested by Das et al. (2007), does the unexpected complexity, cost and increased uncertainty of the international landscape lead entrepreneurs to perceive exports as an unviable strategy? In this latter scenario incentives to withdraw from foreign operations rise and the exit from international markets can become the desired policy. 
The analysis of the relationship between export behaviour and SME's growth in a transition economy is the focus of this study. More concretely, this study analyses the specific impact of different choices related to the transitions in-and-out of exporting-i.e., export entry (new exporter), persistence (habitual exporter), and export exit—on employment growth.

Although the literature often portraits export as a 'harmless' exercise, international success is far from a guaranteed value-adding adventure (Crick, 2003; Mora, 2015). Exportfailure is a likely outcome resulting from the many uncertainties, complexities and high investments related with international venturing (Manolova et al., 2010). When a business' international activity fails, it not only means the loss of its international investments, it can often have a negative effect that reverbs back on the firm's domestic activities (Amiti and Weinstein, 2011). Businesses tend to rely heavily on external finance for their international operations (Smolarski and Kut, 2011), so exporters cannot simply ignore foreign losses (Mora, 2015). They will face domestic financial constraints that may mean fewer financing options for domestic operations, limiting hiring capabilities (Smolarski and Kut, 2011). This is compounded by the fact that small and novice exporters tend to gain smaller export revenues (Rauch and Watson, 2003), which rarely cover the costs of initiating international trade operations in the short-term (Das et al., 2007). Similar to Eaton et al. (2007), Vaillant et al. (2018) recently found that export persistence of new ventures tends to fall after the initial years in export markets, which suggests that exporting results in profit losses for many exporters (Mora, 2015).

The empirical application uses a rich dataset of Romanian SMEs for the year 2008. While existing evidence suggests that Central and Eastern European SMEs are increasingly active internationally (Miocevic and Crnjak-Karanovic, 2011), most of the existent literature on emerging markets focuses on the international behaviour of large firms (Aulakh et al., 2000; Yamakawa et al., 2008). International business scholars highlight the internationalisation of small firms from emerging economies as a fruitful research avenue (Peiris et al., 2012; Ganvir and Dwivedi, 2017). In particular, our data distinguishes businesses that are habitual exporters from those that have just started to export or that have recently stopped exporting. 
The Romanian context is attractive since this Eastern European country has undergone a profound restructuring process that led to its integration to the European Union, radically shifting from a centrally planned system towards a functioning market-oriented economy. One of the most important challenges faced by Romania relates to the development of competitive SMEs (Lafuente and Rabetino, 2011; Smallbone and Rogut, 2005). This is especially evident when looking at the international performance of Romanian SMEs. The statistics provided by the European Commission (2010) indicate that $18 \%$ of Romanian SMEs export, a rate that is below the European average (25\%). This signals that Romanian internationalised SMEs are in a weaker position relative to their European counterparts. Romania is a fertile ground for researching the international behaviour of local firms with little experience in competitive settings. Also, to the best of our knowledge, few empirical studies focus on the differentiated impact over employment growth of the different decisions related to the transitions in-and-out of exporting (Bernard and Jensen, 1999; Requena, 2005), and none of these analyse the exporting-employment growth relation in the Central and Eastern European context. The dearth of research specifically addressing Romanian SMEs’ international involvement and its repercussions on employment growth gives further relevance to the analysis proposed here.

The results of our analysis suggest that, in the European context dominated by competitive markets and low barriers to entry, exporting should not be regarded as an isolated event and research should recognise the importance of simultaneously analysing SMEs' export involvement, continuity, as well as export exit to correctly examine the impact of these strategic decisions on employment growth.

Rather than analysing the international performance link or the canonical relationship between export variables (propensity and intensity) and performance metrics, this study contributes to expand the international entrepreneurship literature by exploring the influence of the business' export cycle in-and-out of international markets on domestic employment.

The paper is organised as follows. Section two presents the theory that underpins the study and the development of the hypotheses. Section three describes the data and the 
methodology. Section four presents the empirical results, while section five provides the conclusions and implications of the study.

\section{Theoretical framework and hypotheses development}

\subsection{The benefits of exporting}

There is increased empirical literature addressing the question of whether foreign market experience enhances business performance (Bernard and Jensen, 1999; Castellani, 2001; Matanda and Freeman, 2009; Miocevic and Crnjak-Karanovic, 2011, Ngo et al., 2016; Peiris et al., 2012; Peres and Stumpo, 2000). The underlying assumption motivating this research stream is that selling in international markets improves performance either through allowing businesses to exploit the expanded scale economies associated with a combined domestic and international market, or by providing businesses with enhanced learning capabilities via access to an enlarged technology set and knowledge spillovers (Manolova et al., 2010; Requena, 2005).

If we introduce to the 'export-performance' connection the analysis of newly created enterprises and SMEs, we find ourselves at the intersection of the international business and entrepreneurship literature, which has developed to be its own scholarly field of enquiry known as international entrepreneurship (Coviello et al., 2011; Keupp and Gassman, 2009; Rialp et al, 2005a). The factors that have been linked with entrepreneurial export-based internationalisation in related research range from knowledge generation processes (Gassmann and Keupp, 2007), networks (Yli-Renko et al., 2002; Manolova et al., 2010), or institutions (Belso-Martinez, 2006), to past performance (Shrader et al., 2000), strategic orientation (Jantunen et al., 2005; Jalal Ahamed and Skallerud, 2015), market discovery processes (Hohenthal et al., 2003) and opportunity recognition ability (Oviatt and McDougall, 2005), or the business’ financial structure (leverage ratio) (Kim, 2016). However, most research in international entrepreneurship treat export propensity or intensity as the dependent variable to which determinant or causal factors are linked (Jones et al., 2011). From a theoretical perspective, notable exceptions are the work by Jones and Coviello (2005) who analyse the lagged self-reinforcing loop of exporting and market performance; and that of Sapienza et al. (2006) who advance a theoretical, 
capability-based framework of the effects of exporting on firm survival and growth. Greenaway and Kneller (2007) and Wagner (2012) offer extensive surveys of empirical work conducted in developed and developing countries on the positive relationship between exports and various performance metrics. In the specific case of emerging economies, recent empirical evidence corroborating the positive effect of exports on business performance can be found in De Loecker, J. (2007) and Dikova et al. (2017) for Slovenia, Atkin et al. (2017) for Egypt, and Vendrell-Herrero et al. (2017) for ten Latin American countries.

The study of the influence of an entrepreneur's choice to enter or exit international markets on overall firm performance falls at the periphery of the international entrepreneurship literature. It can be categorised as part of the 'Internationalisation' area of the 'Entrepreneurial Internationalisation' block within the thematic map of the International Entrepreneurship domain elaborated by Jones et al. (2011, p. 636) as part of their exhaustive literature review of the international entrepreneurship field of research. Although the field of international entrepreneurship has somewhat shifted since its inception, 'there remains a dominant empirical focus on small firms’ (Coviello et al., 2011, p. 627).

The choice of international markets is a significant step in the life of any small and medium-sized firm (Rialp et al, 2005b). This decision brings about important considerations that affect firm's survival and growth (Dimitratos et al., 2010). Exporting remains the most common mechanism chosen by SMEs to enter in international markets (Morgan et al., 2012; Ngo et al., 2016). Exporting is especially appealing to SMEs as it represents a low-commitment entry mode and therefore, the economic cost and risk borne by the entrepreneur are lower compared to alternative foreign entry modes. In the particular case of SMEs operating in emerging countries, there is increased interest in their international performance as these economies are increasingly more integrated into the global market. Additionally, with advancements in information and communication technologies, a wider range of export opportunities have opened up to SMEs in developing countries (Şentürk and Erdem, 2008).

By going international, SMEs not only increase their customer base allowing for greater economies of scale, and thus increasing their growth potential (Girma et al., 2002), but the 
exporting SME can also access more diverse market knowledge transfers that can serve to improve their competitive stance at home. SMEs with foreign sales actively learn from the competitive strategies of their international rivals (Dimitratos et al., 2010). These intangible resources are often an essential element in strategic capability-building that help exporting businesses establish domestic competitive advantages. Benefits of exporting can also be linked to the adoption of innovation strategies which help create and maintain competitive advantage (Acs et al., 1997). These benefits serve the exporting business' survival and growth prospects and have been found to translate into gains for employees in terms of higher wages and better future development prospects (Bernard and Jensen, 1999).

Exporting not only represents a platform to boost the internationalised business' performance and growth, but also creates the conditions to develop organisational knowledge and other capabilities that could help enhance business performance in terms of employment growth (Filatotchev et al., 2009; Manolova et al., 2010; Peiris et al., 2012).

Prior empirical research shows mixed results when analysing the intensity in the relationship between exporting and employment. Bernard and Jensen (1999) shows that the effect of exports on performance is conditioned by the firm's technological regime, as well as by the business' international experience. Using an unbalanced panel of medium and large plants in the US for the period 1984-1992, these authors find that exporting businesses show significantly higher employment growth rates. Leichenko (2000) used regional data for the US during the period 1980-1991 to explain the effect of exports on business performance. The author finds that increases in the proportion of sales abroad have a negative impact on manufacturing businesses’ employment.

In the case of the UK, Westhead et al. (2001) conducted a survey in 1990 and 1997 on a sample of 621 manufacturing, construction and service-oriented businesses. The authors concluded that exports are not significantly correlated with employment. In their analysis of 8,992 UK manufacturing firms during 1988-1999, Girma et al. (2002) found that exporting is positively and significantly correlated with business performance and employment levels. Similarly, Cabrol and Nlemvo (2009) analysed 68 early-internationalised French firms for 2002, 
and found that businesses with a much deeper international orientation-in terms of export intensity—report higher levels of sales and employment.

Research focused on the relationship between exports and growth in emerging market offers mixed results. In their analysis of 582 entrepreneurs from four Latin American economies (Argentina, Brazil, Mexico, and Peru), Capelleras and Rabetino (2008) found that increased export intensity (i.e., change in the export to sales ratio) is positively associated with employment growth. On contrary, Wood et al. (2011) use information for 257 firms located in China, India, Mexico, and South Africa for the year 2002 and find that businesses accumulate knowledge from export activities (learning curves), and that export experience is positively correlated with export intensity. But these authors do not reach a clear conclusion on the influence of international activity on employment.

From the review of the literature it can be deduced that SMEs increasingly use exporting as a way to expand their product demand, and that exporting is conducive to performance. This logic and evidence suggest the following relationship between export and employment growth:

H1: There is a positive relationship between exporting and employment growth

\section{2) Export status and performance}

The process of exporting leads to important changes in firm behaviour and performance, and these changes are likely more pronounced in small firms (Acs et al., 1997; Peiris et al., 2012). Yet, at this point the main question rising is whether changes in the export status, that is, from export entry to export exit, have a distinctive impact on employment growth.

Movements in-and-out of international markets are times of substantial change for any business (Greenaway and Kneller, 2007). According to Bernard and Jensen (1999) small firms experience a significant improvement as a result of a switch from non-exporter to exporter, while businesses that interrupt exporting have quantitatively equivalent negative performance. This suggests that the benefits of exporting activity occur quickly among small firms entering export markets (Requena, 2005). Yet, uncertainty, poor information regulatory requirements, 
raw material specificities or market conditions can lead new exporters to make costly mistakes, thus increasing the initial investment necessary to effectively enter into new foreign markets.

In the case of businesses with more experience in international markets, the accumulated experience would lead to greater benefits from exporting, which can translate in the development of a greater contact network that may facilitate the access to distribution channels and selling points (Bernard and Jensen, 1999; Requena, 2005). In this scenario, performance improvements would come with time. Businesses with a more regular export activity and greater international experience would have to accommodate their operations and capabilities to the international conditions in the short run. Once the business is fully 'equipped' and actively participating in the international market, its capacity to increase operations as a result of exporting experience would help the business achieve performance improvements that would be observable in the mid-and-long run. This way, the potential adaptation cost of adopting specific technologies or processes linked to regulatory or market constraints in overseas markets, together with the business' learning capacity during the immediate post-entry period are critical aspects that contribute to explain the likeliness of success in its international activity (Das et al., 2007). As a result, the outcome of exporting would be observable after the business consolidates operations in the foreign markets.

There are few papers dealing with the performance consequences of transitions in-andout of exporting. In their longitudinal analysis of medium and large US plants, Bernard and Jensen (1999) find that export entrants significantly improve their performance in the first year of entry into international markets. Compared to non-exporters, firms in the first year of exporting show greater rates of employment growth (5.60\%). Also habitual exporters outperform businesses that exit international markets in terms of employment (Bernard and Jensen, 1999). The results for business that drop international markets (exiters) indicate that, compared to non-exporters, the strategic decision to exit operations in international markets is associated with subsequent performance deterioration in terms of employment. This is consistent with the view that businesses that stop exporting are exposed to potential financial 
losses related to their previous investments; and their operations would likely experience a decrease as a result of their lower activity levels (Crick, 2003; Das et al., 2007).

In their study of Korean and Taiwanese businesses, Aw et al. (2000) provide evidence that when firms switch from being non-exporters to become exporters, their performance is enhanced, whereas switching from being an exporter to selling solely on the domestic market leads to poor performance results. Further evidence is found in Requena (2005) who analyse 1,940 UK SMEs. His results indicate that, compared to non-exporters, new exporters witnessed a substantial increase in their employment level, while businesses that dropped exporting activities suffered significant employment losses. The author also finds that new exporters show significantly higher employment growth rates, and that businesses that stop exporting have significant lower growth rates, compared to both habitual exporters and non-exporters.

Prior research emphasises the need for resources when it comes to engage in international activities. As a result, exporting businesses tend to be larger-in terms of employment - than their non-exporting counterparts, and both new exporters and businesses that interrupt their export activity are larger than non-exporters (Amorós et al., 2016). From the abovementioned arguments our second hypothesis connected with the export status emerges: H2(a): The positive impact of exporting on employment growth is greater among habitual exporters than among new exporters.

H2(b): The relationship between exporting and employment growth is negative among firms that exit international activities.

\section{Data, variable definition and method}

\subsection{Data}

The data used in this study come from the Romanian Centre for Entrepreneurship and Business Research (CEBR) for the year 2008. The database provided by the CEBR was collected between February and April 2009, and it was designed to provide information about selected performance and organisational characteristics of Romanian small and medium sized enterprises, as well as of their corresponding entrepreneurs. Contact information for the target 
SMEs was obtained from the directory created by the CEBR. Data collection by the CEBR was achieved through self-administrated, structured questionnaires where the entrepreneur was asked to answer essentially closed questions. The questionnaire was also subject to a pre-test in order to correct potentially misleading or confusing questions. Previous studies using the data provided by the CEBR can be found in Lafuente and Rabetino (2011), Lafuente and Vaillant (2013) and Lafuente et al. (2015).

The original database contained information for 895 Romanian small and medium sized firms. In the interest of following a rigorous methodology we dropped from the sample those observations with missing values. The final sample comprises information for 566 Romanian SMEs. Following the NUTS criterion, and based on the distribution of the population of active businesses across Romania, we observe that our sample demonstrates an appropriate geographical spread throughout Romania: 19.43\% of firms are located in Bucharest and a significant representation of SMEs can also be found in the Southeast (17.84\%), the North-east (14.66\%) and the Centre (12.90\%) regions (Table 1).

Additionally, the sampled businesses have, on average, 9.58 employees. Concerning the size distribution of the sample, $97.53 \%$ of the sampled businesses have fewer than 50 employees (80.21\% report less than ten employees), whereas the remaining $2.47 \%$ fall in the medium-size category (between 51 and 250 employees). The size distribution of our sample reveals a lower share of micro-enterprises with less than 10 employees, relative to EU figures reported by the European Commission (2016). Finally, note that $24.38 \%$ of the sampled businesses export, and that the highest concentration of exporting businesses was found in the North-eastern region, which is also the region where businesses are—on average—the largest in terms of employment (average employment: 12.46). Businesses operating in the Central (proportion of exporters: 26.03\%), North-west (proportion of exporters: 25.93\%), and Western (proportion of exporters: 23.91\%) regions also report high export propensity levels. 


\subsection{Variable definition}

Dependent variable. Following the approach by Bernard and Jensen (1999), Peres and Stumpo (2000), Davidsson et al. (2002) and Lafuente and Rabetino (2011), performance is measured as employment growth. Employment growth is a key performance dimension for organisations. Davidsson et al. (2006, p. 8) conclude that growth measures based on employment show the highest correlation with alternative growth indicators (sales and assets).

Concerning the way to operationalize growth, two are the most prevalent approaches found in the literature. First, in their study on the determinants of business growth in Eastern Germany, Brixy and Kohaut (1999) propose to measure employment growth as $\ln \left(\right.$ Employment $\left._{i t}\right)-\ln \left(\right.$ Employment $\left._{i t-k}\right)$ to correct skewness in data, where $t$ refers to the year of the survey (2008) and $k$ is the year the business was created. We note that in our sample average employment growth—according to Brixy and Kohaut (1999)—is 83.59\% (skewness: 0.5307) (Table 2). The second growth measure used in this study is based on Davidsson et al., (2002, p. 341), who propose to measure employment growth as

$\left(\right.$ Employment $_{i t}-$ Employment $\left._{i t-k}\right) /\left[\left(\right.\right.$ Employment $_{i t}+$ Employment $\left.\left._{i t-k}\right) / 2\right]$ to obtain an asymptotically normally distributed growth variable. From the descriptive statistics presented in Table 2 we observe that average employment growth—according to Davidsson et al. (2002)—is 66.57\% (skewness: -0.1152). This variable also shows a lower dispersion compared to that reported for the metric proposed by Brixy and Kohaut (1999).

At this point, an important consideration is in order. We are aware that our employment growth measures can be affected by significant variations in the employment level of businesses that started operations with one employee. A further scrutiny of the data reveals that $23.85 \%$ of the sampled businesses started operations with one employee (135 out of 566), and that $47.41 \%$ of these businesses (64 out of 135) did not experience any change in their employment level, that is, they report one employee in 2008. Also, average growth among the group of 135 businesses that started operations with one employee was 0.9139 (Brixy and Kohaut, 1999) and 0.7254 (Davidsson et al, 2002). Although these growth figures for the group of one-employee 
firms are slightly higher than values reported for the whole sample (see Table 2), we found that the difference in employment growth—according to Brixy and Kohaut (1999)—between the group of one-employee businesses (0.9139) and the rest of businesses (0.8115) is weakly significant $(t$-test $=1.73, p$-value $=0.08)$. In the case of the Davidsson et al. (2002) variable, the average growth of one-employee businesses (0.8254) is not significantly different than that reported for the rest of firms $(0.6156)(t$-test $=1.57, p$-value $=0.12)$. These results confirm that our growth estimates are not significantly affected by the potentially disproportionate growth of one-employee businesses, thus validating our approach to growth.

--- Insert Table 2 about here ---

Export behaviour. Concerning the key independent variables, we introduced three different metrics to capture the different dimensions of the export decision. First, we included a dummy variable taking the value of one is the business exports in 2008, and zero otherwise. This variable is linked to the businesses' export propensity, and in our sample we observe that $24.38 \%$ of businesses export (Table 2). The second variable relates to the export intensity of the sampled businesses, measured as the proportion of sales in international markets in 2008. In our sample, businesses export on average 13.07\% of their products/services (Table 2). The data gathered by the CEBR includes information between 2006 and 2008, which allows the observation of changes in the businesses' export behaviour during a three-year period. Therefore, the third export-related variable measures the change in the proportion of sales overseas. The average change in exports reported by the sampled businesses is $2.27 \%$ (Table 2). Export status. We use a set of three dummy variables to capture the potentially differentiating impact on employment growth of different decisions linked to the transitions inand-out of exporting: export entry, persistence, and exit. The variable related to export entry takes the value of one if the business started exporting in 2008. In the sampled Romanian SMEs, 7.95\% of businesses report their first international sales in 2008. Similar to Bernard and Jensen (1999), the second dummy variable takes the value of one if the business is a habitual 
exporter, that is, the business has been selling its products/services abroad for at least two consecutive years. Table 3 shows that $16.43 \%$ of firms report a continuous participation in foreign markets. Finally, the third dummy variable identifies businesses that, after exporting for at least two consecutive years, stop exporting in 2008. In our sample 25 businesses (4.42\%) decided to stop exporting in 2008 to concentrate their business effort in the domestic market.

--- Insert Table 3 about here ---

Control variables. We introduce several control variables related to the entrepreneur's profile and the business profile in the different model specifications. More concretely, the control variables related to the entrepreneur include gender (dummy variable taking the value of one for men), the entrepreneur's age measured in years, and a dichotomous variables that takes the value of one if the entrepreneur has management studies. These variables have been used in prior work dealing with employment growth models (see, e.g., Brown et al., 2005; Capelleras and Rabetino, 2008; Johnsen and McMahon, 2005). Similar to previous research (Audretsch et al., 1999; Davidsson et al., 2002; Evans, 1987; Lafuente and Rabetino, 2011; Mata, 1994), the business-related control variables include business age expressed in years, initial size measured as the number of employees in the first year of operations, and a dummy variable that captures if the business was founded by the entrepreneur solely or by an entrepreneurial team. Finally, a set of regional dummy variables were introduced to rule out the effects of different local economic and institutional environments on employment growth. Note that the variables entrepreneur's age, business age, and business initial size were logged to reduce skewness.

\subsection{Method}

Given the statistical properties of the two growth measures used in this study, and similar to prior work on employment growth (see, e.g., Capelleras and Rabetino, 2008; Davidsson et al., 2002; Hart ad Oulton, 1996; Lafuente and Rabetino, 2011), we employ linear 
regression models estimated via OLS to test the proposed hypotheses that emphasise that employment growth is affected by various dimensions of the business' export behaviour.

To evaluate the role of the analysed export-related factors empirically, we advance a set of baseline models that estimate the employment growth of the sampled businesses as a function of the variables related to the business' export behaviour: export propensity, export intensity, and the change in the proportion of sales overseas. More formally, Employment growth $_{i}=\beta_{0}+\beta_{1}$ Export behaviour $_{i}+\beta_{2}$ Control variables $_{i}+\varepsilon_{i}$

In equation (1), the dependent variable refers to the two employment growth variables used in the study (according to Brixy and Kohaut (1999) and Davidsson et al. (2002)). The term $\beta_{j}$ is the vector of parameter estimates for the $j$ th independent variable and $\varepsilon_{i}$ is the normally distributed error term computed for each business in the sample (i). The variable 'Export behaviour' refers to export propensity, export intensity, and the change in the proportion of sales in international markets. Control variables include factors related to the entrepreneur (gender, age, and management studies), to the business (business age, initial size, and entrepreneurial teams), as well as the regional dummy variables (the omitted variable is Bucharest). Equation (1) will be used to test our first hypothesis on the relationship between export and employment growth (H1). In this case, we expect that $\beta_{1}>0$ to confirm that the international activity of the business—in terms of export propensity, export intensity, and increased sales in foreign markets—-positively impact employment growth.

Next, we run the second model that incorporates the different variables related to the transition in-and-out of exporting: export entry, export exit, and export persistence. This model has the following form:

$$
\begin{aligned}
\text { Employment growth }_{i} & =\beta_{0}+\beta_{1} \text { Export entry }_{i}+\beta_{2} \text { Export persistence }_{i} \\
& +\beta_{3} \text { Export exit }_{i}+\beta_{4} \text { Control variables }_{i}+\varepsilon_{i}
\end{aligned}
$$


In equation (2), the transition-in-and-out of exporting is measured via three dummy variables that take the value of one if the business is a new exporter (export entry), is a habitual exporter (export persistence), or stopped its international activity (export exit). Similar to the case of the set of baseline models (equation 1), the dependent variable is employment growth, measured via the metrics proposed by Brixy and Kohaut (1999) and Davidsson et al. (2002), while the control variables include the entrepreneur's profile (gender, age, and management studies), the business's profile (age, initial size, and entrepreneurial teams) and the regional dummy variables (the omitted variable is Bucharest).

In terms of our hypotheses, we expect that $\beta_{2}>0$ and that $\beta_{2}>\beta_{1}$ to corroborate that the positive impact of exporting on employment growth is greater among habitual exporters than among new exporters (H2a). Also, we expect that $\beta_{3}<0$ to confirm that the relationship between exporting and employment growth is negative among firms that exit international activities (H2b).

\section{Empirical findings and discussion}

\subsection{Transitions in-and-out of exporting and employment growth}

This section presents the results of the empirical analysis. For both employment growth measures (according to Brixy and Kohaut (1999) and Davidsson et al. (2002)), specifications 1 to 3 in Table 4 show the results of the baseline models estimating growth as a function of export propensity, export intensity, and the change in international sales. Model 4 presents the results for the full model including the variables related to the transitions in-and-out of exporting (export entry, export persistence, and export exit).

To address the threat of collinearity, we computed the average variance inflation factor (VIF) for all variables. In all model specifications, the average and maximum VIF values are below the generally accepted threshold value of 10 for assessing collinearity (Greene, 2003). The results for this diagnostic test do not raise collinearity concerns. 
Concerning the control variables, results indicate that the business' initial size is the only significant variable explaining employment growth. This finding is consistent throughout the different model specifications and for the two employment growth measures analysed. The negative result of the coefficient indicates that smaller firms (at the start-up year) show significantly higher growth rates. This result is consistent with prior research highlighting that smaller businesses grow faster (see, e.g., Audretsch et al., 1999; Blackburn et al., 2013; Evans, 1987; Hall, 1987; Lafuente and Rabetino, 2011).

\section{--- Insert Table 4 about here ---}

As for the key findings of the study, results presented in specification 1 in Table 4 indicate that businesses reporting sales in foreign markets show significantly greater employment growth rates. This is consistent for the two analysed employment growth measures. In the case of the growth measure proposed by Brixy and Kohaut (1999) the result indicates that the rate of employment growth among exporters is $19.40 \%$ higher than that of non-exporting businesses. A similar result emerges when analysing the result for the growth measure by Davidsson et al. (2002): the average employment growth rate of exporters is $11.70 \%$ higher than the rate estimated for the group of non-exporting businesses. Nevertheless, these arguments do not hold for the variables linked to export intensity and variations in exports (models 2 and 3 in Table 4). This implies that the positive effect of exporting on employment growth is not conditioned by the intensity with which businesses sell their products/services in international markets. Therefore, we confirm our first hypothesis (H1) that proposes a positive relationship between exporting and employment growth only for the variable linked to export propensity.

In the EU context the low trade costs across member states reduce the psychic distance and economic risk of exporting, regardless of the weight of exports in the business' portfolio (export intensity) (Oviatt and McDougall, 2005; Vaillant et al., 2006). These aspects contribute to explain why SMEs typically export to EU markets (e.g., Dhingra et al., 2018; Lafuente et al., 2015). Therefore, the results in Table 4 pointing to a positive relationship between exports- 
more concretely, export entry—and employment growth may suggest that the sampled firms primarily export to EU markets. To verify this argument, we analysed the foreign markets targeted by new exporters and habitual exporters. Results in Table 5 confirm that the exporting efforts of the study SMEs primarily focus on EU markets. On average, new exporters sell abroad 51.87\% of their products/services, while average export intensity among habitual exporters is $54.44 \%$ (Table 5). A second noteworthy finding relates to the markets targeted by new and habitual exporters. On the one hand, habitual exporters sell to EU countries $88.61 \%$ of their total exports (Table 5: 52.80\%), a result that is significantly higher than that found for new exporters (Table 5: 45.96\%). On the other hand, and despite the relatively low values, sales to markets outside the EU are significantly more prevalent among new exporters (Table 5: 5.91\%), compared to the group of habitual exporters (Table 5: 1.64\%). However, this latter result should be taken with a grain of salt as it may be influenced by the higher proportion of new exporters selling more than $50 \%$ of their sales outside the EU (13.34\%), compared to the proportion of habitual exporters selling to markets outside the EU more than 50\% of their sales (5.38\%).

\section{--- Insert Table 5 about here ---}

Results in model 4 of Table 4 allow at testing hypotheses 2(a) and 2(b). In this case we observe that both employment growth variables are positively associated with the initiation of international activities. The coefficient for the variable 'new exporter' is positive and statistically significant, which indicates that the benefits of exporting-in terms of employment growth—are greater among first-time exporters, compared to non-exporters. For illustrative purposes, in the case of the growth measure by Davidsson et al. (2002), the result of the coefficient for new exporters indicates that employment growth among firms that enter foreign markets is $34.10 \%$ higher than that of non-exporters. The result for the 'habitual exporter' dummy is not significant, which means that the export premium linked to employment growth is not correlated with experience in international markets. This finding is similar to that reported 
by Bernard and Jensen (1999) for the US and by Requena (2005) for the UK, who find no differences in the year-to-year performance changes of habitual exporters and non-exporters.

To correctly test hypothesis H2(a), the comparison of coefficients was used to detect for potential differences in the effect of the variables 'new exporter' and 'habitual exporter' on employment growth. Based on the parameters reported in model 4, the result of the F-test indicates that the positive effect on employment growth of the 'new exporter' dummy is significantly higher than the effect computed for the 'habitual exporter' dummy. This result is consistent across the analysed employment growth measures: F-test $=11.07(p$-value $<0.01)$ for the growth variable by Brixy and Kohaut (1999), and F-test $=8.30$ ( $p$-value $<0.01)$ for the growth variable proposed by Davidsson et al. (2002). These results do not give support to our hypothesis H2(a) that states that the positive impact of exporting on employment growth is greater among habitual exporters than among new exporters.

The coefficient linked to the variable capturing export exit is negative and statistically significant, which indicates that firms that dropped international markets have lower employment growth rates than non-exporting firms. This result is especially relevant because it suggests that the decision to exit exporting activities is related to potential operational losses derived from the misallocation of resources within the business. In this sense, the reported fall in employment may well be a consequence of the business' lower export returns. This way, we confirm our hypothesis H2(b) that proposes that the relationship between exporting and employment growth is negative among firms that exit international activities.

\subsection{Robustness check: Structural break}

In models like ours—in which a linear regression is used to represent an economic relationship - the question often arises as to whether the analysed relationship is stable across the sampled businesses, or whether coefficients remain stable for different groups of businesses.

Similar to the analysis presented in section 3.2 on the potential effect of significant employment changes in businesses that started operations with one employee (23.85\% of the sample: 135 out of 566 businesses), we also acknowledge the possibility that the coefficients 
generated from our employment growth regressions do not hold constant across different types of businesses. More concretely, it is relevant to question if the employment growth pattern of businesses created with one employee is comparable to that of businesses created with more employees. From a statistical perspective, this question can be answered by testing whether two groups of observations-in our case, businesses created with one employee vis-à-vis the rest of businesses in the sample—are part of the same regression model.

To evaluate if two groups of parameter estimates in two regressions are equal, we employ the test developed by Chow (1960). This procedure evaluates if coefficients computed for two groups of observations are significantly different (structural break), thus rendering ordinary least squares (OLS) estimates inefficient and biased (Wooldridge, 2002).

We performed the Chow test (1960) on all regression models presented in Table 4, and the results of the structural break tests are presented in Table 6. From the results reported in Table 6 we cannot reject the null hypothesis that both groups of observations (one-employee business and the rest of businesses) belong to the same regression model (no structural break) (Chow, 1960, p. 604). These results confirm that—for the two employment growth measures used in this study and for all model specifications—-the estimated slopes for the group of businesses that started operations with one employee (at the start-up year) are not significantly different compared to the coefficients computed for the rest of businesses in the sample.

Because estimations are not significantly affected by potential discrepancies in the growth patterns of businesses created with one employee vis-à-vis the rest of businesses in the sample, we therefore conclude that the coefficients of the employment growth models in Table 4 are consistent. These findings reinforce our approach to employment growth.

--- Insert Table 6 about here ---

\subsection{Complementary analysis}

Having corroborated the differentiating effect of the analysed export decisions on employment growth, we conducted an additional analysis to further validate our results. From 
the exhaustive analysis of the sample we note that, compared to non-exporters, exporters are significantly larger in terms of number of employees (Table 7). This result exclusively comes from the employment growth rate of new exporters (the result is significant at $1 \%$ level). Notwithstanding this result, it should be noted that the median size of both new and habitual exporters fall into the micro-business category with less than 10 employees.

Furthermore, the only significant difference in the average employment growth rate was found when comparing new exporters (Brixy and Kohaut: 133\% - Davidsson et al.: 94\%) and non-exporters (Brixy and Kohaut: 80\% - Davidsson et al.: 65\%). This result is similar to that of Calof (1993) and Requena (2005) who find that small firms experience a substantial performance improvement the year they switch from being non-exporters to become exporters. Also, this result is in line with Bernard and Jensen (1999) who report that the benefits of exporting are more pronounced among new exporters than among businesses with more international experience.

--- Insert Table 7 about here ---

Finally, results in Table 7 show that export intensity—measured as the proportion of sales abroad—is evenly distributed among exporting businesses. In line with the regression results presented in Table 4 (models 2 and 3), this finding suggests that employment growth is not linked to higher rates of sales in international markets.

\section{Concluding remarks, implications and limitations}

In this study, we contribute to bridging the link between employment and different export strategies. Our analysis seeks to scrutinise the distinctive effect that the different forms of export behaviours related to the transitions in-and-out of exporting (export entry, export persistence, and export exit) have over employment growth. In doing so, we propose an analysis of the relationship between different forms of export behaviour and employment growth on a sample of 566 Romanian small and medium sized enterprises (SMEs). The relevance of this 
study flows from the particular empirical design that simultaneously evaluates different export choices and their specific effect on employment growth in a transition economy.

The main results emerging from our analysis indicate that exporting firms grow more rapidly than non-exporting firms, in terms of employment. As for the analysis of the effects of transitions in-and-out of exporting, we found that firms entering into international markets show a significantly greater rate of employment growth than their non-exporting counterparts. To the contrary, in the case of habitual exporters our results do not give support to the view that experience in international markets enhances quantitative improvements in employment. Finally, our findings are in line with previous studies indicating that firms that abandon their international activities experience significant operational and financial losses, which translate into lower (or negative) employment growth rates (Bernard and Jensen, 1999; Requena, 2005).

This study has important implications for scholars, practitioners and policy makers. From an academic perspective, our results show that export matters for employment growth, but we highlight the relevance of distinguishing the specific impacts of the different export behaviours analysed related to the transitions in-and-out of exporting. Our findings permit us to corroborate that new exporters grow more rapidly than habitual exporters, thus pointing to the presence of an impulse effect of exporting on employment growth. Previous studies indicate that experience in international markets is important to consolidate international operations; however, it was found that consolidation does not necessarily come with further growth in employment.

In line with the previous arguments, our results are encouraging for practitioners as they suggest that businesses may obtain important gains from initiating export activities. Together with the relative ease of internationalisation through exporting, Romanian businesses may perceive exporting as a valid strategy to grow as a result of the simplification of the bureaucratic work necessary to engage in international activities within the European Union.

Finally, the results of this study also have important implications for policy makers. Because employment creation is an economic policy priority, an important outcome of our study is adding to the stock of empirical evidence showing the positive link between initiating 
export activities and employment creation. Because export exit is associated with net employment lose, policy looking to stimulate domestic employment should be aimed towards encouraging high-potential local firms to explore foreign opportunities and develop export markets. By doing so the findings of this study show that there will be positive repercussions on local employment growth. Even in times of domestic economic slowdown, foreign expansion to international export markets experiencing a more favourable economic situation can help stimulate local industry and lay the seeds for a domestic economic inflection towards greater prosperity. Because our results highlight the significant effect of export entry and export exit on employment growth, policy makers will also be well advised to develop support programmes that not only promote exports among SMEs, but that also accompany and monitor businesses in their export pathway in order to avoid ill-judged export entry decisions and help new exporters to overcome unexpected difficulties that may lead them to exit exporting.

The results of the study do, however, send a warning against the overuse of employment growth as a marker for success and selection of firms participating within export promotion programmes. Because the positive repercussions of exports over employment have been found to exist only among those firms initiating their export market ventures, policy that gauges its impact only on employment may end up excluding all those habitual exporters who have consolidated their export-based internationalisation. Employment growth is one of many relevant dimensions that capture the performance and positive domestic impact of export market consolidation. With inadequate or insufficient support, habitual exporters could easily find themselves leaving international markets. Their exit from export markets will, however, generate negative employment consequences as was found from the results of the study.

The consolidation of SMEs' exports is a top policy priority in Europe (European Commission, 2011). Support throughout the exporting process and bureaucratic assistance are critical elements at the core of most programmes aimed at enhancing exports among European SMEs (European Commission, 2016). We find that management studies and the presence of entrepreneurial teams are not significant factors when it comes to explaining business growth; whereas exporting significantly boosts employment growth among new exporters. Also, we 
found that the quantitative development of employment is more pronounced among smaller firms that recently entered into the international arena. Specific measures should first focus on identifying those businesses with a greater likeliness of export persistence (Vaillant et al., 2018). Second, export promotion policies should better communicate the benefits of exporting to entrepreneurs so that those high-potential SMEs perceive exporting as a low financial commitment entry mode.

We report some limitations that, in turn, represent future research avenues. As with any cross-sectional study, the main limitation of the paper lies in both the absence of a longitudinal analysis that could have given a greater perspective to the study, and the potential presence of selection bias. Also, the data used in this study coincides with Romania's accession to the EU, a period during which businesses may have had different incentives to export, compared to other time periods. Future research should replicate similar studies in other emerging contexts—either within Central and Eastern Europe or elsewhere-and using more recent data so the results could be compared and ultimately generalised to larger populations. Performance is a multidimensional construct. Therefore, future research should pay attention to the long run repercussions that exporting is having on alternative performance measures other than employment growth. Finally, future research should not only attempt to explore the observed differences in the impact of exporting on SMEs' performance, but should also verify whether different organizational attributes help to explain (i.e., moderate) the relationship between export activity and business performance, such as industry, number of targeted countries, or international experience of the entrepreneur, in order to further build on our analysis.

\section{References}

Acs, Z., Morck, R., Shaver, J.M. and Yeung, B. (1997) “The Internationalisation of Small and Medium-Sized Enterprises: A Policy Perspective”, Small Business Economics, Vol. 9, pp. 720. 
Amorós, J.E., Basco, R. and Romaní, G. (2016) “Determinants of early internationalisation of new firms: the case of Chile”, International Entrepreneurship and Management Journal, Vol. 12 No. 1, pp. 283-307.

Amiti, M. and Weinstein, D.E. (2011) “Exports and financial shocks”, Quarterly Journal of Economics, Vol. 126, pp. 1841-1877.

Atkin, D., Khandelwal, A.K. and Osman, A. (2017) "Exporting and firm performance: evidence from a randomized experiment”, Quarterly Journal of Economics, Vol. 132, pp. 551-615.

Audretsch, D., Santarelli, E. and Vivarelli, M. (1999) “Start-up size and industrial dynamics: some evidence from Italian manufacturing”, International Journal of Industrial Organization, Vol. 17 No. 7, pp. 965-983.

Aulakh, P.S., Kotabe, M. and Teegen, H. (2000) “Export Strategies and Performance of Firms from Emerging Economies: Evidence from Brazil, Chile, and Mexico”, Academy of Management Journal, Vol. 43 No. 4, pp. 342-361.

Aw, B.Y., Chung, S. and Roberts, M. (2000) "Productivity and turnover in the export market: Micro-level evidence from the Republic of Korea and Taiwan (China)”, World Bank Economic Review, Vol. 14, pp. 65-90.

Belso-Martinez, J.A. (2006) "Why are some Spanish manufacturing firms internationalizing rapidly? The role of business and institutional international networks”, Entrepreneurship \& Regional Development, Vol. 18 No.3, pp.207-226.

Bernard, A. and Jensen, J.B. (1999) “Exceptional exporter performance: cause, effect, or both?”, Journal of International Economics, Vol. 47, pp. 1-25.

Blackburn, R.A., Hart, M. and Wainwright, T. (2013) "Small business performance: Business, strategy and owner-manager characteristics”, Journal of Small Business and Enterprise Development. Vol. 20 No. 1, pp. 8-27.

Brixy, U. and Kohaut, S. (1999) "Employment Growth Determinants in New Firms in Eastern Germany”, Small Business Economics, Vol. 13, pp. 155-170. 
Brown, J., Earle, J. and Lup, D. (2005), “What makes small firms grow? Finance, human capital, technical assistance, and the business environment in Romania”, Economic Development and Cultural Change, Vol. 54 No. 1, pp. 33-70.

Cabrol, M. and Nlemvo, F. (2009) “The internationalisation of French new ventures: The case of the Rhone-Alps region”, European Management Journal, Vol. 27, pp. 255-267.

Calof, J.L. (1993) “The mode choice and change decision process and its impact on international performance”, International Business Review, Vol. 2 No. 2, pp. 97-120.

Capelleras, J.L. and Rabetino, R. (2008) “Individual, organizational and environmental determinants of new firm employment growth: evidence from Latin America”, International Entrepreneurship and Management Journal, Vol. 4 No. 1, pp. 79-99.

Castellani, D. (2001) “Export behaviour and productivity growth: evidence from Italian manufacturing firms”, Review of World Economics, Vol. 138 No. 4, pp. 605-628.

Chow, G.C. (1960) “Tests of equality between sets of coefficients in two linear regressions”, Econometrica, Vol. 28 No. 3, pp. 591-605.

Coviello, N., McDougall, P. and Oviatt, B. (2011) “The emergence, advance and future of international entrepreneurship research—An introduction to the special forum”, Journal of Business Venturing, Vol. 26 No. 6, pp. 625-631.

Crick, D. (2003) “The international entrepreneurial decision of UK SMEs to discontinue overseas activities: A research note reporting practices within the clothing industry eighteen months on”, Journal of International Entrepreneurship, Vol. 1 No. 4, pp. 405-413.

Das, S., Roberts, M.J. and Tybout, J.R. (2007) “Market entry costs, producer heterogeneity, and export dynamics”, Econometrica, Vol. 75, pp. 837-873.

Davidsson, P., Delmar, F. and Wiklund, J. (2006) Entrepreneurship and the Growth of Firms, Elgar, Cheltelham.

Davidsson, P., Kirchhoff, B., Hatemi-J, A. and Gustavsson, H. (2002) "Empirical Analysis of Employment Growth Factors Using Swedish Data”, Journal of Small Business Management, Vol. 40 No. 4, pp. 332-349. 
De Loecker, J. (2007) “Do exports generate higher productivity? Evidence from Slovenia”, Journal of International Economics, Vol. 73 No. 1, pp. 69-98.

Dhingra, S., Ottaviano, G., Rappoport, V., Sampson, T. and Thomas, C. (2018) “UK trade and FDI: A post-Brexit perspective”, Papers in Regional Science, Vol. 97 No. 1, pp. 9-24.

Dikova, D., Jaklič, A., Burger, A., and Kunčič, A. (2016) "What is beneficial for first-time SME-exporters from a transition economy: A diversified or a focused export-strategy?”, Journal of World Business, Vol. 51 No. 2, pp. 185-199.

Dimitratos, P., Plakoyiannaki, E., Pitsoulaki A. and Tuselmann H. (2010) “The global smaller firm in international entrepreneurship”, International Business Review, Vol. 19, pp. 589-606.

Eaton, J., Eslava, M., Kugler, M. and Tybout, J. (2007) “Export dynamics in Colombia: Firmlevel evidence”, Technical report, National Bureau of Economic Research.

European Commission (2010) Internationalisation of European SMEs. Brussels:

Entrepreneurship Unit. Available at http://ec.europa.eu.

European Commission (2011) Small business, big world - a new partnership to help SMEs seize global opportunities. Communication from the commission to the European Parliament, the Council, the European Economic and Social Committee and the Committees of the Regions. Available at http://eur-lex.europa.eu.

European Commission (2016). Annual Report on European SMEs 2015/2016: SME recovery continues. Luxembourg: Publications Office of the European Union. Available at http://ec.europa.eu.

Evans, D. (1987) “Tests of alternative theories of firm growth”, Journal of Political Economy, Vol. 95 No. 4, pp. 658-674.

Filatotchev, I., Liu, X. Buck, T. and Wright, M. (2009) “The export orientation and export performance of high-technology SMEs in emerging markets: The effects of knowledge transfer by returnee entrepreneurs”, Journal of International Business Studies, Vol. 40, pp. 1005-1021. 
Ganvir, M.B., Dwivedi, N. (2017) “Internationalization and performance of Indian born globals: Moderating role of presence of foreign equity”, International Journal of Emerging Markets, Vol. 12 No. 1, pp.108-124

Gassmann, O. and Keupp, M.M. (2007) “The competitive advantage of early and rapidly internationalizing SMEs in the biotechnology industry: a knowledge-based view”, Journal of World Business, Vol. 42 No. 3, pp. 350-366.

Girma S., Greenaway D. and Kneller R. (2002) “Does exporting lead to better performance? A microeconomic analysis of matched firms”, Working paper, University of Nottingham, March.

Greenaway, D., and Kneller, R. (2007) “Firm heterogeneity, exporting and foreign direct investment”, The Economic Journal, Vol. 117, pp. F134-F161.

Greene, W. (2003) Econometric Analysis. Prentice Hall, Upper Saddle River, New Jersey.

Hall, B. (1987) "The relationship between firm size and firm growth in the US manufacturing sector”, Journal of Industrial Economics, Vol. 35 No. 4, pp. 583-606.

Hart, P. and Oulton, N. (1996) “Grow and size of the firms”, Economic Journal, Vol. 106 No. 438, pp. 1242-1252.

Hohenthal, J., Johanson, J. and Johanson, M. (2003) “Market discovery and the international expansion of the firm”, International Business Review, Vol. 12, pp. 659-672.

Jalal Ahamed, A.F.M., Skallerud, K. (2015) “The link between export relationship quality, performance and expectation of continuing the relationship: A South Asia exporters' perspective”, International Journal of Emerging Markets, Vol. 10, No. 1, pp.16-31.

Jantunen, A., Puumalainen, K., Saarenketo, S. and Kylaheiko, K. (2005) “Entrepreneurial orientation, dynamic capabilities and international performance”, Journal of International Entrepreneurship, Vol. 3, No. 3, pp. 223-243.

Johnsen, G. and McMahon, R. (2005), “Owner-manager gender, financial performance and business growth amongst SMEs from Australia’s business longitudinal survey”, International Small Business Journal, Vol. 23 No. 2, pp. 115-140. 
Jones, M. and Coviello, N. (2005). “Internationalization: conceptualising an entrepreneurial process of behavior in time”, Journal of International Business Studies, Vol. 36 No. 3, pp. 284-303.

Jones, M., Coviello, N. and Tang, Y.K. (2011) “International Entrepreneurship research (19892009): A domain ontology and thematic analysis”, Journal of Business Venturing, Vol. 26 No. 6, pp. 632-659.

Keupp, M.M. and Gassmann, O. (2009) “The past and the future of international entrepreneurship: a review and suggestions for developing the field”, Journal of Management, Vol. 35, No. 3, pp. 600-633.

Kim, H.S. (2016) “Firms’ leverage and export market participation: Evidence from South Korea”, International Economics, Vol. 148, pp. 41-58.

Lafuente, E. and Rabetino R. (2011) "Human Capital and Growth in Romanian Small Firms”, Journal of Small Business and Enterprise Development, Vol. 18 No. 1, pp. 74-96.

Lafuente, E., Stoian, C. and Rialp, J. (2015) “From Export Entry to De-internationalisation through Entrepreneurial Attributes”, Journal of Small Business and Enterprise Development, Vol. 22 No. 1, pp. 21-37.

Lafuente, E. and Vaillant, Y. (2013) “Age Driven Influence of Role-Models on Entrepreneurship in a Transition Economy”, Journal of Small Business and Enterprise Development, Vol. 20 No. 1, 181-203.

Lamb, P., Sandberg, J. and Liesch, P.W. (2011) “Small firm internationalisation unveiled through phenomenography”, Journal of International Business Studies, Vol. 42 No. 5, pp. 672-693.

Leichenko, M.R. (2000) "Exports, Employment, and Production: A Causal Assessment of U.S. States and Regions”, Economic Geography, Vol. 76 No. 4, pp. 303-325.

Manolova, T.S., Manev, I.M. and Gyoshev, B.S. (2010) “In good company: The role of personal and inter-firm networks for new-venture internationalisation in a transition economy”, Journal of World Business, Vol. 45 No. 3, pp. 257-265.

Mata, J. (1994) "Firm growth during infancy”, Small Business Economics, Vol. 6, 7-39. 
Matanda, M.J. and Freeman S. (2009) "Effect of perceived environmental uncertainty on exporter-importer inter-organisational relationships and export performance improvement”, International Business Review, Vol. 18, pp. 89-107.

Miocevic, D. and Crnjak-Karanovic, B. (2011) “Cognitive and Information-Based Capabilities in the Internationalisation of Small and Medium-Sized Enterprises: The Case of Croatian Exporters”, Journal of Small Business Management, Vol. 49 No. 4, pp. 537-557.

Mora, J. (2015) “Export Failure and Its Consequences: Evidence from Colombian Exporters”, Working paper series, Department of Economics, Occidental College (California, USA).

Morgan, N.A., Katskieas, C.S. and Vrohies, D.W. (2012) “Export marketing strategy implementation, export marketing capabilities, and export venture performance”, Journal of the Academy of Marketing Science, Vol. 40 No. 2, pp. 271-289.

Ngo, V.D., Janssen, F. and Falize, M. (2016) “An incentive-based model of international entrepreneurship in emerging and transition economies”, Journal of International Entrepreneurship, Vol. 14 No. 1, pp. 52-74.

Oviatt, B.M. and McDougall, P.P. (2005) “Defining international entrepreneurship and modeling the Speed of Internationalization”, Entrepreneurship Theory \& Practice, Vol. 29, No. 5, pp. 537-553.

Peiris, I.K., Akoorie, M.E. and Sinha P. (2012) “International entrepreneurship: a critical analysis of studies in the past two decades and future directions for research”, Journal of International Entrepreneurship, Vol. 10 No. 4, pp. 279-234.

Peres, W. and Stumpo, G. (2000) "Small and Medium-Sized Manufacturing Enterprises in Latin America and the Caribbean under the New Economic Model”, World Development, Vol. 28 No. 9, pp. 1643-1655.

Rauch, J.E. and Watson, J. (2003) “Starting small in an unfamiliar environment”, International Journal of Industrial Organisation, Vol. 21, pp. 1021-1042.

Requena, F. (2005) “Changing export status and firm performance: evidence from UK small firms”, Applied Economic Letters, Vol. 12, pp. 567-571. 
Rialp, A., Rialp, J. and Knight, G.A. (2005a) “The phenomenon of early internationalizing firms: what do we know after a decade (1993-2003) of scientific inquiry?”, International Business Review, Vol. 14, No. 2, pp. 147-166.

Rialp, A., Rialp, J., Urbano, D. and Vaillant, Y. (2005b) “The born-global phenomenon: a comparative case study research”, Journal of International Entrepreneurship, Vol. 3, No. 2, pp. 133-171.

Sapienza, H.J., Autio, E., George, G. and Zahra, S.A. (2006) “A capabilities perspective on the effects of early internationalization on firm survival and growth”, Academy of Management Review, Vol. 31, No. 4, 914-933.

Şentürk, I. and Erdem, C. (2008) "Determinants of Export Propensity and Intensity of SMEs in Developing Countries: An Empirical Analysis of Turkish Firms”, Empirical Economics Letters, Vol. 7 No. 2, pp. 171-179.

Shrader, R.C., Oviatt, B.M. and McDougall, P. (2000) "How new ventures exploit trade-offs among international risk factors: lessons for the accelerated internationalization of the 21st century”, Academy of Management Journal, Vol. 43, No. 6, pp. 1227-1247.

Smallbone, D. and Rogut, A. (2005) “The challenge facing SMEs in the EU’s new member states”, International Entrepreneurship and Management Journal, Vol. 1 No. 2, pp. 19-40.

Smolarski, J. and Kut, C. (2011) “The impact of venture capital financing method on SME performance and internationalisation”, International Entrepreneurship and Management Journal, Vol. 7 No. 1, pp. 39-55.

Vaillant, Y., Lafuente, E., and Bayon, M. (2018), “Early internationalization patterns and export market persistence: A pseudo-panel data analysis”, Small Business Economics, in press, doi: 10.1007/s11187-018-0071-z

Vaillant, Y., Urbano Pulido, D., Rialp Criado, J., and Rialp Criado, A. (2006) “Un estudio cualitativo y exploratorio de cuatro nuevas empresas exportadora”, Cuadernos de Economía y Dirección de la Empresa, Vol. 29, pp. 107-132.

Vendrell-Herrero, F., Gomes, E., Mellahi, K. and Child, J. (2017) “Building international business bridges in geographically isolated areas: The role of foreign market focus and 
outward looking competences in Latin American SMEs”, Journal of World Business, Vol. 52 No. 4, pp. 489-502.

Westhead, P., Wright, M. and Ucbasaran, D. (2001) “The internationalisation of new and small firms: a resource-based view”, Journal of Business Venturing, Vol. 16 No. 4, pp. 333-358.

Wood, E., Khavul S., Perez-Nordtvedt, L., Prakhya, S., Velarde Dabrowski, R. and Zheng, C. (2011) “Strategic Commitment and Timing of Internationalisation from Emerging Markets: Evidence from China, India, Mexico, and South Africa”, Journal of Small Business Management, Vol. 49 No. 2, pp. 252-282.

Wooldridge, J. (2002) Econometric Analysis of Cross Section and Panel Data. The MIT Press, Cambridge, MA.

Yamakawa, Y., Peng, M.W. and Deeds, D.L. (2008) "What drives new ventures to internationalise from emerging to developed economies?”, Entrepreneurship Theory and Practice, Vol. 32 No. 1, pp. 59-82.

Yli-Renko, H., Autio, E. and Tontti, V. (2002) “Social capital, knowledge, and the international growth of technology-based new firms”, International Business Review, Vol. 11, No. 3, pp. 279-304. 


\section{List of Tables}

Table 1. Geographic distribution and main characteristics of the sampled businesses

\begin{tabular}{lccccc}
\hline & \multicolumn{4}{c}{ Information on the sampled businesses } & Regional data \\
\hline & $\begin{array}{c}\text { Employment } \\
\text { in 2008 }\end{array}$ & $\begin{array}{c}\text { Exporters } \\
\text { (in \%) }\end{array}$ & $\begin{array}{c}\text { Number of } \\
\text { observations }\end{array}$ & $\begin{array}{c}\text { Proportion } \\
\text { (in \%) }\end{array}$ & $\begin{array}{c}\text { Proportion of active } \\
\text { firms in 2015 (in \%) }\end{array}$ \\
\hline Bucharest & 10.21 & 21.82 & 110 & 19.43 & 20.05 \\
Centre & 8.19 & 26.03 & 73 & 12.90 & 12.69 \\
West & 4.93 & 23.91 & 46 & 8.13 & 9.19 \\
North-west & 7.59 & 25.93 & 54 & 9.54 & 15.17 \\
South-west & 9.26 & 21.43 & 42 & 7.42 & 7.69 \\
South & 8.68 & 19.30 & 57 & 10.07 & 11.76 \\
North-east & 12.46 & 31.33 & 83 & 14.66 & 12.53 \\
South-east & 11.36 & 23.76 & 101 & 17.84 & 10.92 \\
\hline Total & $\mathbf{9 . 5 8}$ & $\mathbf{2 4 . 3 8}$ & $\mathbf{5 6 6}$ & $\mathbf{1 0 0 . 0 0}$ & $\mathbf{1 0 0 . 0 0}$ \\
\hline
\end{tabular}

Note: The regional distribution follows the NUTS-3 criterion (EUROSTAT). Regional data on the proportion of active businesses was obtained from Eurostat databases

(http://ec.europa.eu/eurostat/web/regions/data/database)

Table 2. Descriptive statistics for the selected variables

\begin{tabular}{|c|c|c|c|c|}
\hline Variable & Average & $\begin{array}{l}\text { Standard } \\
\text { deviation }\end{array}$ & Minimum & Maximum \\
\hline $\begin{array}{l}\text { Employment growth } \\
\text { (Brixy and Kohaut, 1999) }\end{array}$ & 0.8359 & 1.0129 & -2.9957 & 4.4659 \\
\hline $\begin{array}{l}\text { Employment growth } \\
\text { (Davidsson et al., 2002) }\end{array}$ & 0.6657 & 0.7400 & -1.8095 & 1.9545 \\
\hline \multicolumn{5}{|l|}{ Entrepreneur's Profile } \\
\hline Gender (male) & 0.6820 & 0.4661 & 0 & 1 \\
\hline Age (years) & 37.3922 & 8.3300 & 18 & 60 \\
\hline Education in management & 0.5530 & 0.4976 & 0 & 1 \\
\hline \multicolumn{5}{|l|}{ Business profile } \\
\hline Firm age (years) & 6.1908 & 5.1034 & 1 & 19 \\
\hline Start up size (employees) & 3.8463 & 8.7883 & 1 & 120 \\
\hline Employment in 2008 & 9.5813 & 16.2563 & 1 & 160 \\
\hline Entrepreneurial team & 0.5177 & 0.5001 & 0 & 1 \\
\hline \multicolumn{5}{|l|}{ Export-related variables } \\
\hline Export propensity & 0.2438 & 0.4298 & 0 & 1 \\
\hline Export intensity & 0.1307 & 0.2787 & 0 & 1 \\
\hline Change in international sales & 0.0227 & 0.2052 & -1 & 1 \\
\hline New exporter & 0.0795 & 0.2708 & 0 & 1 \\
\hline Habitual exporter & 0.1643 & 0.3709 & 0 & 1 \\
\hline Export exit & 0.0442 & 0.2056 & 0 & 1 \\
\hline
\end{tabular}

Total number of observations: 566 businesses. 
Table 3. Export behaviour: Distribution of firms according to the export status

\begin{tabular}{|c|c|c|c|c|}
\hline & $\begin{array}{l}\text { Employment growth } \\
\text { (Brixy and Kohaut) }\end{array}$ & $\begin{array}{l}\text { Employment growth } \\
\text { (Davidsson et al.) }\end{array}$ & Observations & Proportion \\
\hline Non-exporter & $\begin{array}{c}0.8054 \\
(0.9799)\end{array}$ & $\begin{array}{c}0.6515 \\
(0.7321)\end{array}$ & 403 & 71.20 \\
\hline $\begin{array}{l}\text { Exporter } \\
\text { (in 2008) }\end{array}$ & $\begin{array}{c}0.9685 \\
(1.0798)\end{array}$ & $\begin{array}{c}0.7445 \\
(0.7544)\end{array}$ & 138 & 24.38 \\
\hline a) New exporter & $\begin{array}{c}1.3326 * * * \\
(1.3100)\end{array}$ & $\begin{array}{c}0.9447 * * \\
(0.8310)\end{array}$ & 45 & 7.95 \\
\hline $\begin{array}{l}\text { b) Habitual } \\
\text { exporter }\end{array}$ & $\begin{array}{c}0.7923 \\
(0.9051)\end{array}$ & $\begin{array}{c}0.6477 \\
(0.6986)\end{array}$ & 93 & 16.43 \\
\hline Export exit & $\begin{array}{c}0.5971 \\
(1.1124) \\
\end{array}$ & $\begin{array}{c}0.4586 \\
(0.7619) \\
\end{array}$ & 25 & 4.42 \\
\hline Total & $\begin{array}{c}0.8359 \\
(1.0129)\end{array}$ & $\begin{array}{c}0.6657 \\
(0.7400)\end{array}$ & 566 & 100.00 \\
\hline \multicolumn{5}{|c|}{$\begin{array}{l}\text { Note: The 'Exporter (in 2008)' category includes both new exporters that started internationalizing in } \\
2008 \text { and habitual exporters with more than two years exporting. Standard deviation is presented in } \\
\text { brackets. The } t \text {-test evaluates differences in employment growth between exporting businesses (new } \\
\text { exporter and habitual exporter) and the non-export group, as well as between business that stopped } \\
\text { exporting in } 2008 \text { and the non-exporting group. }{ }^{*}, * *, * * * \text { indicates significance at the } 0.10,0.05 \text { and } \\
0.01 \text {, respectively (two-tailed } t \text {-test). }\end{array}$} \\
\hline
\end{tabular}


Table 4. Regression results: Effect of export on employment growth

\begin{tabular}{|c|c|c|c|c|c|c|c|c|}
\hline & \multicolumn{4}{|c|}{ Employment growth (Brixy and Kohaut, 1999) } & \multicolumn{4}{|c|}{ Employment growth (Davidsson et al., 2002) } \\
\hline & Model 1 & Model 2 & Model 3 & Model 4 & Model 1 & Model 2 & Model 3 & Model 4 \\
\hline Gender (Male) & $0.102(0.086)$ & $0.104(0.087)$ & $0.110(0.086)$ & $0.111(0.086)$ & $0.075(0.063)$ & $0.076(0.064)$ & $0.795(0.064)$ & $0.078(0.064)$ \\
\hline $\begin{array}{l}\text { Entrepreneur } \\
\text { age (ln) }\end{array}$ & $-0.228(0.205)$ & $-0.224(0.206)$ & $-0.210(0.205)$ & $-0.210(0.203)$ & $-0.135(0.143)$ & $-0.133(0.144)$ & $-0.124(0.144)$ & $-0.126(0.142)$ \\
\hline $\begin{array}{l}\text { Management } \\
\text { studies }\end{array}$ & $0.022(0.082)$ & $0.024(0.082)$ & $0.030(0.082)$ & $0.033(0.081)$ & $0.052(0.060)$ & $0.054(0.060)$ & $0.058(0.060)$ & $0.060(0.060)$ \\
\hline $\begin{array}{l}\text { Initial size (ln } \\
\text { employees) }\end{array}$ & $-0.410(0.052)^{* * *}$ & $-0.412(0.523) * * *$ & $-0.414(0.052)^{* * *}$ & $-0.423(0.513)^{* * *}$ & $-0.308(0.039)^{* * *}$ & $-0.309(0.039) * * *$ & $-0.031(0.038) * * *$ & $-0.317(0.038)^{* * *}$ \\
\hline $\begin{array}{l}\text { Business age } \\
\text { (ln) }\end{array}$ & $0.037(0.044)$ & $0.033(0.044)$ & $0.028(0.043)$ & $0.023(0.043)$ & $0.024(0.031)$ & $0.022(0.031)$ & $0.019(0.031)$ & $0.019(0.031)$ \\
\hline $\begin{array}{l}\text { Entrepreneurial } \\
\text { team }\end{array}$ & $-0.014(0.08)$ & $-0.012(0.078)$ & $-0.157(0.080)$ & $-0.034(0.080)$ & $-0.021(0.058)$ & $-0.020(0.058)$ & $-0.022(0.058)$ & $-0.034(0.058)$ \\
\hline Exporter & $0.194(0.099)^{* *}$ & & & & $0.117(0.070)^{*}$ & & & \\
\hline $\begin{array}{l}\text { Proportion of } \\
\text { foreign sales }\end{array}$ & & $0.173(0.156)$ & & & & $0.102(0.117)$ & & \\
\hline $\begin{array}{l}\Delta \text { in foreign } \\
\text { sales }\end{array}$ & & & $0.372(0.273)$ & & & & $0.252(0.175)$ & \\
\hline Export entry & & & & $0.590(0.181)^{* * *}$ & & & & $0.341(0.117)^{* * *}$ \\
\hline Export exit & & & & $-0.322(0.195)^{*}$ & & & & $-0.282(0.143)^{* *}$ \\
\hline $\begin{array}{l}\text { Habitual } \\
\text { exporter }\end{array}$ & & & & $-0.027(0.104)$ & & & & $-0.017(0.078)$ \\
\hline $\begin{array}{l}\text { Regional } \\
\text { dummies }\end{array}$ & Yes & Yes & Yes & Yes & Yes & Yes & Yes & Yes \\
\hline Intercept & $1.773(0.711)^{* *}$ & $1.790(0.715)^{* *}$ & $1.757(0.713)^{* *}$ & $1.752(0.704)^{* *}$ & $1.241(0.500)^{* *}$ & $1.251(0.502)^{* *}$ & $1.231(0.502)^{* *}$ & $1.240(0.450)^{* *}$ \\
\hline Adjusted R2 & \begin{tabular}{|l|}
0.1202 \\
\end{tabular} & 0.1156 & 0.1190 & \begin{tabular}{|l|}
0.1412 \\
\end{tabular} & \begin{tabular}{|l|}
0.1258 \\
\end{tabular} & \begin{tabular}{|l|}
0.1227 \\
\end{tabular} & 0.1261 & 0.1414 \\
\hline $\mathrm{F}-$ test & $8.45 * * *$ & $8.19 * * *$ & $8.52 * * *$ & $8.22 * * *$ & $8.86 * * *$ & $8.45 * * *$ & $8.98 * * *$ & $9.06 * * *$ \\
\hline $\begin{array}{l}\text { Average VIF } \\
(\min -\max )\end{array}$ & $\begin{array}{c}1.07 \\
(1.01-1.25) \\
\end{array}$ & $\begin{array}{c}1.07 \\
(1.01-1.25) \\
\end{array}$ & $\begin{array}{c}1.07 \\
(1.01-1.25) \\
\end{array}$ & $\begin{array}{c}1.07 \\
(1.01-1.26) \\
\end{array}$ & $\begin{array}{c}1.07 \\
(1.01-1.25) \\
\end{array}$ & $\begin{array}{c}1.07 \\
(1.01-1.25) \\
\end{array}$ & $\begin{array}{c}1.07 \\
(1.01-1.25) \\
\end{array}$ & $\begin{array}{c}1.07 \\
(1.01-1.26) \\
\end{array}$ \\
\hline RMSE & 0.9501 & 0.9525 & 0.9507 & 0.9386 & 0.6918 & 0.6931 & 0.6917 & 0.6857 \\
\hline Observations & 566 & 566 & 566 & 566 & 566 & 566 & 566 & 566 \\
\hline
\end{tabular}

Robust standard errors adjusted by heteroskedasticity are presented in brackets. ${ }^{*}, * *, * * *$ indicates significance at the $0.10,0.05$ and 0.01 , respectively. 
Table 5. Export behaviour: Distribution of international sales according to the targeted markets

\begin{tabular}{llllr}
\hline & Exports in 2008 & Exports within the EU & Exports outside the EU & \multicolumn{1}{c}{ Obs. } \\
\hline New exporter & $0.5187(0.3141)$ & $0.4596(0.3805)^{*}$ & $0.0591(0.1651)^{* *}$ & 45 \\
Habitual exporter & $0.5444(0.3218)$ & $0.5280(0.3275)$ & $0.0164(0.0834)$ & 93 \\
\hline Total exporters & $\mathbf{0 . 5 3 6 0 ( \mathbf { 0 . 3 1 8 4 } )}$ & $\mathbf{0 . 5 0 5 7 ( \mathbf { 0 . 3 4 1 0 } )}$ & $\mathbf{0 . 0 2 7 9}(\mathbf{0 . 1 1 2 2})$ & $\mathbf{1 3 8}$ \\
\hline
\end{tabular}

For the variables related to export intensity (Exports in 2008) and to the businesses' international target market (Exports within the EU and Exports outside the EU), the $t$-test refers to differences in variable means between new exporters that started internationalising in 2008 against habitual exporters with more than two years exporting. *, **, *** indicates significance at the $0.10,0.05$ and 0.01 , respectively (two-tailed $t$-test).

Table 6. Structural break: Results of the Chow test

\begin{tabular}{lcccc}
\hline $\begin{array}{l}\text { Regression } \\
\text { models (Table 4) }\end{array}$ & \multicolumn{2}{c}{$\begin{array}{c}\text { Employment growth } \\
\text { (Brixy and Kohaut, 1999) }\end{array}$} & \multicolumn{2}{c}{$\begin{array}{c}\text { Employment growth } \\
\text { (Davidsson et al., 2002) }\end{array}$} \\
\hline & F-value & $p$-value & F-value & $p$-value \\
\hline Model 1 & 0.96 & 0.4606 & 0.78 & 0.6065 \\
Model 2 & 1.18 & 0.3109 & 0.91 & 0.4964 \\
Model 3 & 1.40 & 0.2025 & 1.22 & 0.2868 \\
Model 4 & 0.87 & 0.5536 & 0.63 & 0.7712 \\
\hline
\end{tabular}

Note: For each model, the Chow test compares parameters estimated for businesses created with one employee vs. coefficients estimated for the rest of businesses in the sample.

Table 7. Export behaviour: Distribution of firms according to the export status

\begin{tabular}{|c|c|c|c|c|c|c|}
\hline & $\begin{array}{c}\text { Firm size } \\
\text { (employees) }\end{array}$ & $\begin{array}{l}\text { Firm age } \\
\text { (years) }\end{array}$ & $\begin{array}{l}\text { Exports } \\
\text { in } 2008\end{array}$ & $\begin{array}{l}\text { Employment growth } \\
\text { (Brixy and Kohaut) }\end{array}$ & $\begin{array}{l}\text { Employment growth } \\
\text { (Davidsson et al.) }\end{array}$ & Obs. \\
\hline $\begin{array}{l}\text { Non- } \\
\text { exporter }\end{array}$ & $\begin{array}{c}8.52 \\
(12.55)\end{array}$ & $\begin{array}{c}6.31 \\
(5.10)\end{array}$ & N.A. & $\begin{array}{c}0.8054 \\
(0.9799)\end{array}$ & $\begin{array}{c}0.6515 \\
(0.7321)\end{array}$ & 403 \\
\hline $\begin{array}{l}\text { Exporter in } \\
2008\end{array}$ & $\begin{array}{c}13.36 * * * \\
(24.26)\end{array}$ & $\begin{array}{c}5.65 \\
(4.95)\end{array}$ & $\begin{array}{c}0.5360 \\
(0.3184)\end{array}$ & $\begin{array}{c}0.9685 \\
(1.0798)\end{array}$ & $\begin{array}{c}0.7445 \\
(0.7544)\end{array}$ & 138 \\
\hline $\begin{array}{l}\text { a) New } \\
\text { exporter }\end{array}$ & $\begin{array}{c}23.18 * * * \\
(35.73)\end{array}$ & $\begin{array}{c}6.60 \\
(5.25)\end{array}$ & $\begin{array}{c}0.5187 \\
(0.3141)\end{array}$ & $\begin{array}{c}1.3326 * * * \\
(1.3100)\end{array}$ & $\begin{array}{c}0.9447^{* *} \\
(0.8310)\end{array}$ & 45 \\
\hline $\begin{array}{l}\text { b) Habitual } \\
\text { exporter }\end{array}$ & $\begin{array}{c}8.61 \\
(14.00)\end{array}$ & $\begin{array}{l}5.19 * * \\
(4.76)\end{array}$ & $\begin{array}{c}0.5444 \\
(0.3218)\end{array}$ & $\begin{array}{c}0.7923 \\
(0.9051)\end{array}$ & $\begin{array}{c}0.6477 \\
(0.6986)\end{array}$ & 93 \\
\hline Export exit & $\begin{array}{c}5.80 \\
(10.46)\end{array}$ & $\begin{array}{c}7.12 \\
(5.90) \\
\end{array}$ & N.A. & $\begin{array}{c}0.5971 \\
(1.1124)\end{array}$ & $\begin{array}{r}0.4586 \\
(0.7619) \\
\end{array}$ & 25 \\
\hline Total & $\begin{array}{c}9.58 \\
(16.24)\end{array}$ & $\begin{array}{c}6.19 \\
(5.10)\end{array}$ & $\begin{array}{c}0.1307 \\
(0.2787)\end{array}$ & $\begin{array}{c}0.8359 \\
(1.0129)\end{array}$ & $\begin{array}{c}0.6657 \\
(0.7400)\end{array}$ & 566 \\
\hline
\end{tabular}

Note: The 'Exporter in 2008' category includes both new exporters that started internationalizing in 2008 and habitual exporters with more than two years exporting. Standard deviation is presented in brackets. For the variables related to firm size (employees), firm age and employment growth, the $t$-test refers to differences in variable means between groups of firms reporting some export activity (new exporter, exiter and habitual exporter) against the non-exporter group. ${ }^{*}, * *, * * *$ indicates significance at the $0.10,0.05$ and 0.01 , respectively (two-tailed $t$-test). 